\title{
Development of civil commitment statutes (laws of involuntary detention and treatment) in Sri Lanka: A historical review
}

\author{
de Alwis LAP*
}

\begin{abstract}
Civil commitment is the legal process through which a state can deprive individuals of their liberty based on mental illness. Legal statues of civil commitment are as old as the first therapeutic asylums of the Western world. The evolutions of these standards over the last two centuries reflect the changing landscape of psychiatry, the law and social attitudes towards people with mental illness. In Sri Lanka, the Mental Diseases Ordinance codifies the statuary standards of civil commitment. The current legislature dates back to the Lunacy Ordinance of 1873 . The law as it stands was last amended in 1956. The historical development of the civil commitment standards of the current Mental Diseases Ordinance of Sri Lanka reflects similar developments that took place in English mental health law in the 19th and 20th Century. This article summarises the development of civil commitment standards from early $19^{\text {th }}$ century to modern times in Sri Lanka.
\end{abstract}

Key words: Civil Commitment, Ceylon, History

\section{Full paper}

\section{Introduction}

Civil commitment is the legal process through which a state can deprive individuals of their liberty based on mental illness. ${ }^{[1]}$ During this process, individuals may be detained in mental health facilities for containment and/or treatment against their will. It is a process which is regulated by the law in most countries. Civil commitment is considered to be the primary intersection between psychiatry and the law ${ }^{[2]}$. Civil commitment statutes are probably the most important of all forensic mental health laws as they affect the largest number of individuals out of all of the law-mental health interactions. ${ }^{[3]}$ For example,

Consultant Forensic Psychiatrist, National Institute of Mental Health, Sri Lanka

*Corresponding author: de Alwis, LAP, 109/3A, Lanka Matha road, Mahabage, Sri Lanka. Email: angelo.dealwis@gmail.com

DOI: http://doi.org/10.4038/mljsl.v5i1.7351

https://orcid.org/0000-0002-1101-7129 when an individual patient is detained in an authorised mental health facility under the respective civil commitment law, it not only effects the individual being detained, but also society at large through considerations of risk and human rights.Legal statues of civil commitment are as old as the first therapeutic asylums of the Western world. The evolutions of these standards over the last two centuries reflect the changing landscape of psychiatry, the law and social attitudes towards people with mental illness. These changes have been viewed by some as a swinging pendulum ${ }^{(2)}$, oscillating between more and less restriction of individual liberty and by others as a spiral, continuously advancing the quality of care even while vacillating between more and less restrictive legislature. $^{[4]}$

In Sri Lanka, the Mental Diseases Ordinance codifies the statuary standards of civil commitment. ${ }^{[5]}$ This law stipulates the procedure to follow when admitting individuals to mental hospitals of the country as well

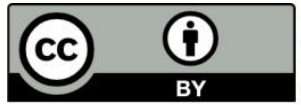

This is an open-access article distributed under the terms of the Creative Commons Attribution License, which permits unrestricted use, distribution and reproduction in any medium, provided the original author and source are credited. 
as when governing the material assets of those found 'unsound mind' under the act.

The current legislature dates back to the Lunacy Ordinance of $1873 .{ }^{[6]}$ The law as it stands was last amended in 1956. Sri Lanka has been in the process of developing a new Mental Health Act since year $2000 .^{[7]}$ A new mental health law is being considered at present, but is still in the early stage. Thus, a review of the history of the development of the current mental health law is considered timely, given that many are unaware of the evolution of legal standards civil commitment over the last two centuries to become what it is today.

\section{Mental illness in early Sri Lanka (Ceylon)}

The modern western approach to psychiatry was introduced to the Indian subcontinent by the British. The British established a legal framework as well as institutions to house the mentally ill beginning in early $19^{\text {th }}$ century. ${ }^{[8]}$

The care of the mentally ill was not an unknown concept in ancient Sri Lanka. According to the Mahawansa, hospitals with relatively sophisticated treatment methods are known to have existed in Sri Lanka as far back as the $4^{\text {th }}$ century BC. ${ }^{[9]}$ The Sarartha Sanghrahaya by King Buddhadasa (362 409 AD), an Ayurvedic medical treatise written in Sanskrit, details the treatment of many illnesses including insanity. Moreover, King Kirthi Sri Rajasinghe (1747-1782 AD) described the use of Buddhist doctrine in the treatment of mental illness. ${ }^{[10]}$

The indigenous system of medical care in ancient Sri Lanka (Sinhala Vedakama) was heavily influenced by Ayurveda, Siddha, Unani systems and their derivatives. $^{[10]}$ The Ayurveda system considers psychiatry as an integral part of medicine. The classical writers of Ayurveda, Charaka and Vagbhatta describe the phenomenology of mental illnesses as well as attempt a classification of mental illnesses based on an aetiological point of view. ${ }^{[11]}$ The indigenous system also appears to have been influenced by prevalent cultural beliefs. Demonological and astrological remedies were commonly used side by side with medicines in the treatment of mental illnesses. ${ }^{[12]}$

In ancient Sri Lanka the mentally ill were considered to be influenced by the supernatural. Robert Knox in his Historical Relation of the Island Ceylon reports that an individual who was possessed (which he claims the people called 'Pissowetitch') were considered to have the 'spirit of the Gods' within him and 'whatsoever he pronounceth, is looked upon as spoken by God himself, and the people will speak to him, as if it were the very person of God' ${ }^{[13]}$ This reverence afforded to the mentally ill, is likely to have placed them at a higher social status than the mentally ill in the Western world. Thus, it is not surprising that until the colonisation of Sri Lanka by the Portuguese, Dutch and British there is no evidence to suggest there was large scale segregation of mentally ill from society.

In the early years of Sri Lankan colonisation, the Portuguese, Dutch and British incarcerated the mentally in the jails along with criminals. ${ }^{[14]}$ With urbanization of the Maritime Provinces under the rule of these western powers it is likely that the insane became an annoyance. The first piece of legislature that provided for civil commitment was introduced by the British in 1839. Prior to the 1839 Ordinance, none of the different systems of law existing at that time in Sri Lanka had comparable legislature providing provisions for the civil commitment of individuals. All references related to insanity, contained in the Roman Dutch law, Kandyan law and Muslim law were about contracts (including matrimony) and maintenance. ${ }^{[15]}$

\section{Early legal determinations of insanity by the British in Sri Lanka}

The earliest legal determination of insanity in Sri Lanka, the author was able to identify, is documented in the correspondence of the First British Governor of Ceylon, Frederick North (1798-1805) with the 
Secretary of State in Great Britain. In a letter dated $25^{\text {th }}$ of November 1802, the governor informs the Secretary of State about a 'senior civil servant' of the Board of Revenue and Commerce, by the name of James Scott Hay, being declared a 'lunatic' ('after a long and minute examination \& inspection') and being 'committed to the care of his registrar by the Supreme Court of Ceylon'. ${ }^{[16]}$ The Royal Charter of Justice of 1801 establishing the Supreme Courts of the Island of Ceylon provided the legal framework for this determination. ${ }^{[17]}$ Through this legislature the Judges of the Supreme Court were instructed to follow the rules and procedures of the High Court of Chancery in Great Britain as well as to adhere to the customary laws of Sri Lanka. Article 41 of the Charter, detailed the Supreme Court's authority in the determination insanity and the appointment of guardians for the person and estates of those who were 'deprived of their Understanding or Reason by the Act of God, so as to be unable to govern themselves and their Estates'(sic).

\section{Regulation No 2 of 1829: An Ordinance to give Jurisdiction to the Provincial Courts in cases of Idiocy and Lunacy not otherwise provided for}

In 1829, the Governor of Ceylon, Edward Barnes, submitted Regulation No 2 to the Executive Council for consideration and enactment. In his submission Edward Barnes stated the absence of legislature that gave authority for courts other than the Supreme Courts to make determinations on insanity in Sri Lanka. ${ }^{[18]}$ Regulation No 2 of 1829: An Ordinance to give Jurisdiction to the Provincial Courts in cases of Idiocy and Lunacy not otherwise provided for, gave the Provincial Courts the jurisdiction to appoint guardians for the persons and the property of those with mental illness. ${ }^{[19]}$ It had provisions for the "trial of questions of idiocy and lunacy' and for the 'appointment of guardians of the persons and estates of idiots and lunatics'. The question of an individual's insanity or idiocy was determined by the presiding Provincial Judge, taking into account witness statements and his own 'personal inspection and examination' of the respondent. If the Provincial Judge made a determination that the 'supposed idiot or lunatic to be of unsound mind', he could proceed to appoint a 'fit and proper' guardian for the person and for his or her estates. Even though the legal test for unsoundness in this context is undefined, a consideration that the Provincial judge was expected to make, was whether the 'supposed idiot or lunatic cannot, with safety to him or herself, or to the public, be left without control'.

The Provincial Judge was also given authority to appoint commissioners to make the assessment on behalf of him when the suspected 'lunatic or idiot' could not be produced before him. These commissioners had to be the 'most respectable inhabitants, living as near as may be to the residence of the supposed idiot or lunatic'. The commissioners had the authority to administer oaths and to hear and write down evidence. This evidence and their opinions regarding the 'state of mind of the supposed lunatic or idiot' had to be communicated to the Provincial Judge who made the final decision on the question of insanity. Thus, Regulation No 2 of 1829 had a common sense approach to the determination of the question of insanity and no expert opinions to assist this decision were called for. Medical expertise may have contributed to the determination of insanity if one or more of the commissioners appointed under this ordinance were medical professionals.

Regulation No 2 of 1829 had no provisions for civil commitment of individuals. Those determined to be unsound were handed over to the care and custody of guardians. The decisions made under this ordinance could be appealed to the High courts. Upon recovery of the mental illness, a similar inquiry conducted by the provincial judge would determine the necessity of a continuation or cessation of guardianship.

This ordinance was nullified by the Charter of Justice of $1833 .{ }^{[20]}$ Judicial reforms introduced by the Charter of 1833 appointed District Courts over the 'care and custody of the persons and estates of all idiots, lunatics and other insane and nonsane mind residents' of their respective districts. 


\section{Regulation No 3 of 1839: To establish Lunatic Asylums, and make general provisions for the safe custody and care of insane persons}

Regulation No 3 of 1839 was the first law of civil commitment in Sri Lanka. ${ }^{[21]}$ Incarceration of the mentally ill in jails (without a criminal conviction) prior to this ordinance is most likely to have occurred under the predecessors of the current vagrancy act. ${ }^{[22]}$ In a submission to the Executive Council on the $29^{\text {th }}$ November 1839, the then Governor of Ceylon states that 'insane persons in the common gaol', are a 'source of great annoyance to the prisoners and the other inmates'. He appeals to the council members to enact the law considering 'distress and misery' of insane persons being cared for in improper establishments. ${ }^{[23]}$

The 1839 Ordinance was directed mainly at the mentally ill paupers and vagrants. At the time of enactment, Sri Lanka did not have any purpose built lunatic asylums. Carpenter in his book on the History of Mental Health Care in Sri Lanka reports that the British began to house the mentally ill in the Leper's asylum in Hendalla during this time. ${ }^{[14]}$ Thus, it is likely that the mentally ill were initially committed under this act to the prisons and to the Leper's asylum in Hendalla until the first lunatic asylum was built in 1847 in Borella. The lunatic asylum to be built under this ordinance was to be established, maintained and governed by the colonial government. The act envisaged the establishment of a lunatic asylum in the Western Province (in Colombo) and later in other provinces of the country.

The presence or absence of privately owned lunatic asylums (madhouses) in Sri Lanka is not known. No licensing legislation can be found for private madhouses enacted by the Governor and the Legislative Council during or after this period. Taking into consideration, the wording of the 1839 Ordinance, which states the objective of the ordinance as to establish 'proper' lunatic asylums and the submission of the Governor to the Executive Council, it can be conjectured that there probably were privately run madhouses at least in the maritime provinces given the extent of the problem and the financial investment made by the then British Government to solve it.It is worth noting that these steps were taken more than two decades before the General Hospital Colombo (1864) and the Colombo Medical School (1870) was established.

The 1839 Ordinance gave authority for District Judges to commit insane paupers, insane vagrants and dangerous lunatics (defined in the act as any person that 'has been discovered and apprehended under any circumstances which denote a derangement of mind and purpose of committing some crime, for which, if committed, he would be liable to be persecuted') to a lunatic asylum. ${ }^{[21]}$ Section 5 of the ordinance made provision for the commitment of mentally ill, who had relatives or friends who were willing to provide for expenses of caring and maintaining them in a lunatic asylum.

The District Judge was required by the law to 'view and examine' the respondent as well as call for evidence from a medical officer or practitioner when available. Thus the 1839 Ordinance appears to depart from the common sense approach of determining the question of insanity and broach a more sophisticated expert evidence based determination. (However, by 1840 this requirement to obtain an expert opinion from a medical professional was removed from the legislature by the Ordinance No 11 of 1840 which repealed this ordinance). ${ }^{[24]}$

Once the determination was made that the respondent was an 'insane pauper or vagrant, or a dangerous lunatic, or idiot' and that no relative of friend would be willing to undertake the care and custody of this individual the District judge had to commit the person to a lunatic asylum or if there was no lunatic asylum in the district, handover the respondent to the Fiscal to be incarcerated until the person can be transferred to an lunatic asylum. Thus the ordinance required all those determined to be of unsound mind 
under the act to be incarcerated in asylums or prisons. This requirement in the 1839 legislature eventually led to overcrowding of prisons and the lunatic asylums. ${ }^{[14]}$ This statute also had provisions for the commitment of those who were found to be unfit to stand trial, those acquitted on grounds of insanity (Section 6) as well as for prisoners with mental illness (Section 7). Release from the lunatic asylum could only be secured through recovery from insanity (which had to be certified by the medical officer of the lunatic asylum and ratified by the Governor) or when family or friends accepted the care and custody of the individual.

\section{Lunacy Ordinance, 1873: An Ordinance relating to the care and custody of Persons of unsound mind, and their Estates}

The legislature which was to become the current Mental Health Ordinance was originally enacted in 1873. ${ }^{[6]}$ This statute repealed the Ordinance No 11 of 1840 and Regulation No 2 of 1829 (which was being kept viable through the Rules and Orders made by the Judges of the Supreme Court for regulating the proceedings of the District Courts). This statute is likely to have been influenced by the Lunacy Act of 1845 of Britain. The acts share similarities in terms of requiring medical expertise in the determining the state of unsoundness and the degree of judicial oversight in the process of civil commitment. The statutes previous to the Lunacy Ordinance of 1873 only provided for the confinement and treatment of those who the District Court was satisfied as being either an insane pauper or vagrant, or a dangerous lunatic or idiot. The Lunacy Ordinance of 1873 broadened this criteria and made provisions for any individual to be confined and treated if the district court believes them to be of unsound mind without reference to their circumstances. ${ }^{[6]}$ While broadening the power of the District Court the 1873 Act introduced a safeguard in the form of the need to produce a medical certificate from a medical practitioner who has provided care for the individual in question in all applications made by private citizens.
Determination of unsoundness was made through 'view and examination' by a district court judge, through 'other evidence' (which included medical evidence) and 'further observation' through remanding the individual in question in the custody of the Fiscal. The importance of medical expertise in detecting someone with 'unsoundness of mind' was emphasised in a report submitted to the Legislative Council by the Subcommittee appointed to report on the 1873 Bill. They recommended a compulsory period of observation in the instance of a conflict of opinion in the form of the district Judge finding an individual to be of sound mind while two medical officers making a finding to the contrary. The Subcommittee wrote that 'a Judge may be inclined, judging only from the language and demeanour of a person brought before him, to consider him quite sane: if the medical practitioners, who have had better opportunities of judging of the state of mind, are of different opinion, it is right that he should be subjected to further observation before he is discharged'. ${ }^{[25]}$ Considering the number of individuals who were imprisoned and the general overcrowding in prisons in late $19^{\text {th }}$ century Ceylon, it is doubtful how these periods of observation in goals would have been useful for the determination of the question of unsoundness. It is however clear that the provisions contained within the Lunacy Ordinance of 1873 represented the most detailed and the most scientific method of determining the question of unsoundness used in Sri Lanka up to that time.

\section{Amendments to the Lunacy Ordinance of 1873}

From 1873 to 1956 nine amendments were made to the Lunacy Ordinance. Except for Act No 27 of 1956: Mental Diseases (Amendment) Act, all of the other amendments did not make any significant contribution to the civil commitment standards in Sri Lanka. (Table 1). However, during the same period, English Mental Health Law underwent major revision from the Lunacy Act of 1845 (On which the Lunacy Ordinance of 1873 was modelled). The Lunacy Act of 1890 and the Mental Treatment Act of 1930 made substantial changes in the standards of civil commitment in the England. For unknown reasons these changes were not reflected in Sri 
Lanka. This was highlighted by Professor Edward

(Mapother Report). ${ }^{[14,26]}$

Mapother in a report that was published in 1938

Table 1: Amendments to the Mental Diseases Ordinance since 1873

\author{
Ordinance Amendment \\ Number \\ Ordinance No 3 An Ordinance to amend "The Lunacy Ordinance, 1873." Made amendments to the appeal process to \\ of 1882 the Supreme Court by including more parties with right of appeal than what was specified in the 1873 \\ act \\ Ordinance No 3 An Ordinance for the regulating the Procedure of the Courts of Criminal Judicature \\ of 1883 \\ Enactment of the Criminal Procedure Code of the country
}

Ordinance No 2 An Ordinance to consolidate and amend the laws relative to the procedure of the Civil Courts Changes of 1889 were made in Chapter XXXIX: Actions in Lunacy; Sections 555 - 581 added to the Civil Procedure Code. These sections dealt with the appointment of a guardian and the management of material assets of those who are found to be of unsound mind by due course of law.

Ordinance No An Ordinance to promote the Despatch of Public Business. Made amendments to the duties and taxes 13 of 1905 embodied within No 1 of 1873.

Ordinance No An Ordinance to amend "The Lunacy Ordinance, 1873." Added provisions dealing with the "capture 16 of 1919 of escaped lunatics'. By adding these provisions the Colonial government sought to bring the law in line with the English law of that time. It added Section 21 which allowed for the release on trial, with power to retake in the event of relapse.

Ordinance No 3 An Ordinance to amend "The Lunacy Ordinance."

of 1940

The provision making the local District court the competent authority to inquire into the state of mind of people suspected of lunacy was removed and the Colombo District Court was made the competent authority to make this assessment of people kept under custody

Ordinance No An Ordinance to amend "The Lunacy Ordinance." A provision introduced to delegate the power of the 13 of 1940 Governor to the 'Minister of Health'. Wherever the 'Governor' was mentioned in the 1873 Ordinance was substituted by 'Minister'. 
Ordinance No An Ordinance to amend "The Lunacy Ordinance." Further provisions were made provide a batta or 11 of 1943 cost of conveyance to the homes of those who are discharged from Angoda

Act No 14 of An Act to Amend the Lunacy Ordinance. Added an amendment that delegated the power of discharge 1952 to the Superintendent of the mental hospital with an intention to avoid unnecessary delay in the discharge of lunatics who have been cured

Act No 22 of Administrative Districts Act. Established administrative districts as the area of authority of 1955 Government Agents.

Act No 27 of Mental Diseases (Amendment) Act

1956

Substitution of the word 'Lunacy' with the words 'Mental Disease'. Provisions were included introducing the emergency, voluntary and temporary admissions to the Angoda Mental Hospital.

\section{The Mapother Report and its effects on the civil commitment standards in Sri Lanka}

Professor Mapother conducted a comprehensive survey of the Angoda Asylum and the mental health care in Sri Lanka (then Ceylon) and out lined a thirteen point programme to improve mental health care in the country. The foundation of these proposals was a complete revision of the existing Lunacy Ordinance. ${ }^{[14]}$ Professor Mapother noted that the existing Lunacy Ordinance dealt with mental illness 'more like crime than a disease'. The report noted that the existing law had not contemplated treatment as an option and had focussed on 'segregation of those dangerous to others and in some measure to protect from segregation any against whom a plot might be framed'(sic). He recommended changes in the Lunacy Ordinance that would enable 'voluntary' and 'temporary' admission patients to be provided with treatment. Despite four amendments being made after the Mapother report was published, it was only in 1956 that some of these recommendations were incorporated into the mental health law of the country.

\section{Act No 27 of 1956: Mental Diseases (Amendment) Act}

The Mental Diseases Act of 1956 made substantial changes to the civil commitment standards in Sri Lanka. The act introduced 'temporary', 'voluntary' and 'emergency' admission to the existing legislature. This amendment was a direct result of the Mapother recommendations of $1938 .{ }^{[27]}$ The act incorporated some of the progressive changes seen in the English Mental Treatment Act of 1930. This act also abolished the word 'lunacy' and introduced the words 'mental disease' in its place.

In the second reading of this act in Parliament, the then Cabinet Minister of Health in Ceylon, Hon. E.A. Nugawela stated, 'Our Lunacy Ordinance was enacted in 1873. Hon. Members are aware of the difficulty people have to undergo in getting a patient treated at or entered to the Mental Hospital. In order to facilitate treatment of mental disorders and to bring our care, observation and treatment of mental patients into line with modern thought and standards, it is imperative to modernise legislation governing admissions to our mental hospital'. He also noted that the new act will change the 'old idea' that admission 
to the mental institution is for the sole purpose of custody and care. ${ }^{[27]}$

The types of admissions elucidated in the The Mental Diseases Act of 1956 remain identical in the current Mental Health Law. The Mental Diseases Act of 1956 provided for the confinement of an individual who is suspected of being unsound mind who needs to be confined in an emergency due to risk to self or others ('being violent and uncontrollable'). This Act also contained provisions for the reception of voluntary and temporary patients. Following the amendment adults could admit themselves to the mental hospital for treatment voluntarily. Under the 'temporary' admission criteria, an individual could be admitted to a mental hospital involuntarily if two medical practitioners make such recommendation without having to go before a district court. The criteria for a temporary patient seems unclear with legislature defining such a patient as 'a person who is suffering from a mental illness and is likely to benefit from temporary treatment in a mental hospital but is for the time being incapable of expressing himself as willing or willing to receive such treatment'. The criterion on face value appears to have some similarity to the common law test for capacity. Once achieving the function of being capable of expressing oneself to communicate whether one wishes to receive treatment or not, the person can be detained under the status of a temporary patient for only 28 days. The superintendent of the hospital would have the authority to discharge temporary patients without informing the district court. Thus the 1956 amendment for the first time allowed the civil commitment of individuals to take place without formal judicial procedure with the involvement of medial practitioners only.

\section{Conclusion}

The historical development of the civil commitment standards of the current Mental Diseases Ordinance of Sri Lanka reflects similar developments that took place in the English mental health law in the $19^{\text {th }}$ and $20^{\text {th }}$ Century. The colonial government and the postindependence governments incorporated 12 amendments to the original ordinance influenced by the evolving English standards as well as by an awareness of the suffering of those with mental illness. The major revision of the mental health law in 1956 can be considered as the best effort made to bring the legislature on par with modern standards of mental health care. Since this amendment, six decades ago, Sri Lanka has seen two civil uprisings, the end of an ethnic conflict and a devastating Tsunami. Sri Lankan society has changed culturally and economically since the passage of the Mental Diseases (Amendment) Act of 1956. The civil commitment standards that exist within the current Mental Diseases Ordinance have become quite outmoded and have contributed little to the development of services in the country. A new mental health act is urgently needed to reconcile the statutory standards of civil commitment with the ground realities of modern Sri Lanka.

\section{References}

1. Pinals DA, Mossman D. Civil Commitment. New York: Oxford University Press; 2012. (Best Practices in Forensic Mental State Assessment)

2. Anfang SA, Appelbaum PS. Civil Commitment - The American Experience. Isr J Psychiatry Relat Sci. 2006; 43(3): 20918

3. Bloom JD. Thirty-Five Years of Working with Civil Commitment Statutes. J Am Acad Psychiatry Law. 2004; 32:430-39

4. Sumathipala A, Hanwella R. The evolution of psychiatric care -- a spiral model. Psychiatric Bulletin. 1996; 20(9):561-3.

5. Mental Diseases Ordinance, No 27 of 1956 (internet). [cited 2016 Feb 9]. Available from:

http://www.commonlii.org/lk/legis/consol_a ct/md559196.pdf

6. Ordinance No 1 of 1873: An ordinance relating to the care and custody of persons of unsound mind and their estates. In: White $\mathrm{H}$, Loos HA. A revised edition of the legislative enactments of Ceylon (internet). Colombo: G J A Skeen, Govt Printer; 1900. Lunacy Act 1873; p.686-91. [cited 2016 Feb 9]. 
Available from: https://archive.org/details/arevisededition00 ceylgoog

7. Weerasundera R. Mental health legislation in Sri Lanka: the time for change is now. SL J Psychiatry. 2011; 2 (2):43-44

8. Mills J. Modern Psychiatry in India: The British Role in the establishing an Asian system (1858-1947). Int Rev Psychiatry August. 2006; 18(4): 333-43

9. Mueller-Dietz HE. Stone "Sarcophagi" and Ancient Hospitals in Sri Lanka. Medizinhistorisches Journal. 1996; 31(1/2): 49-65

10. Uragoda CG. A history of medicine in Sri Lanka from the earliest times to 1948. Colombo. Sri Lanka Medical Association; 1987

11. Neki JS. Psychiatry in South-East Asia. Brit. J. Psychiat. 1973; 123(574), 257-69

12. Dickman H. Treatment of Diseases by Charms, as Practised by the Sinhalese in Ceylon. Transactions of the Ethnological Society of London. 1863; Vol. 2: 140-46

13. Knox R. An Historical Relation of the Island Ceylon in the East-Indies. 1681. Gutenberg E Book. [cited 2016 Feb 9]. Available from: http://www.gutenberg.org/files/14346/14346 -h/14346-h.htm

14. Carpenter J. History of Mental Health Care in Sri Lanka. Colombo: Marga publications; 1988

15. Armour J, Perera JM. Armour's Grammar of the Kandyan Law: Methodically Arranged and Digested, with a Copious Index, Glossary, and Appendix. Colombo: "Examiner" Press; 1861

16. J. Scott Hay, 25.11.1802, 5/2/92, Mottau Index 1896-1835, National Archives of Sri Lanka
17. Article 41, The Royal Charter of Justice of 1801, National Archives of Sri Lanka

18. Minutes of Council from 13 October 1828 to 21 June 1830, National Archives of Sri Lanka - Lot 2/17 - Proceedings of Executive Council, 25 July 1829

19. Regulation No 2 of 1829: An Ordinance to give Jurisdiction to the Provincial Courts in cases of Idiocy and Lunacy not otherwise provided for. In: A Collection of Legislative Acts of the Ceylon Government from 1796: Containing proclamations, regulations, charters, and orders in council; from 1796 to 1833. (Google EBook) Colombo: W Skeen, Government Printer; 1853. [cited 2016 Feb 9]. Available from: https://play.google.com/store/books/details?i $\mathrm{d}=8 \mathrm{uYyAQA}$ AMAAJ $\& \mathrm{hl}=\mathrm{en}$

20. Charter of Justice of 1833, In: A Collection of Legislative Acts of the Ceylon Government from 1796: Containing proclamations, regulations, charters, and orders in council; from 1796 to 1833. (Google EBook) Colombo: W Skeen, Government Printer; 1853. [cited 2016 Feb 9]. Available from: https://play.google.com/store/books/details?i $\mathrm{d}=8 \mathrm{uYyAQAAMAAJ} \& \mathrm{hl}=\mathrm{en}$

21. Ordinance No 3 of 1839: To establish Lunatic Asylums, and make general provisions for the safe custody and care of insane persons. In: Collection of Legislative Acts of the Ceylon Government from 1796: Distinguishing Those Now in Force. V. 1-2 ... 1796/1833-1833/1852. (Google EBook) Colombo: W Skeen, Government Printer; 1854. [cited 2016 Feb 9]. Available from: http://books.google.com.au/books?id=OXQ ZAAAAYAAJ

22. Regulation No. 12 of 1806: Regulation for compelling the Native Headman to the more effective discharge of their duty and for the authorizing Magistrates to apprehend Vagrants. In: A Collection of Legislative 
Acts of the Ceylon Government from 1796:

Distinguishing Those Now in Force. V. 1-2 ... 1796/1833-1833/1852. (Google EBook) Colombo: W Skeen, Government Printer; 1854. [cited 2016 Feb 9]. Available from: http://books. google. com. au/ books?id=OXQZAAAAYAAJ

23. Minutes of the Executive Council, 29 November 1839, National Archives. Sri Lanka

24. Ordinance No 11 of 1840: To amend the law relative to the establishment of Lunatic Asylums, and to make further general provisions for the proper care and custody of insane persons. In: Collection of Legislative Acts of the Ceylon Government from 1796: Distinguishing Those Now in Force. V. 1-2 ... 1796/1833-1833/1852. (Google EBook) Colombo: W Skeen, Government Printer; 1854. [cited 2016 Feb 9]. Available from: http://books.google.com.au/ books?id=OXQZAAAAYAAJ

25. Report of a Sub-Committee of the Legislative Council appointed to report on the Bill: " An Ordinance relating to the care and custody of person of unsound mind and their estates' XVI:Lunacy Bill. Ceylon Sessional Papers. Government Printer. Ceylon. 1872. National Archives. Sri Lanka

26. Mills JH, Jain S. Mapother of the Maudsley and the psychiatry at the end of the Raj. In: Mahone S, Vaughan M. editors. Psychiatry and the Empire.Basingstoke: Palgrave Macmillan; 2007. p. 153-171 (Cambridge imperial and post-colonial studies series)

27. EA Nugawela, Minister of Health. February 10, 1956. Parliamentary Debates (Hansard) (Ceylon: House of Representatives). col. 2249-2250, National Archives. Sri Lanka 